P-ISSN 2580 - 7781

E-ISSN $2615-3238$

\title{
IMPLEMENTASI INFORMATION RETRIEVAL SYSTEM UNTUK KLASIFIKASI BERITA OFFLINE DI INDONESIA MENGGUNAKAN METODE EXTENDED BOOLEAN
}

\section{IMPLEMENTATION OF INFORMATION RETRIEVAL SYSTEM FOR CLASSIFICATION OF OFFLINE NEWS IN INDONESIA USING THE EXTENDED BOOLEAN METHOD}

\author{
Suhardi $^{1)}$ Walim $^{2)}$ Hananda Priyandaru ${ }^{3)}$ Wahyudi Prabowo ${ }^{4)}$ \\ Herlambang Priatmojo ${ }^{5)}$ \\ Universitas Bina Sarana Informatika \\ ${ }^{1}$ Email: suhardi.sdw@bsi.ac.id
}

\begin{abstract}
ABSTRAK
Berita merupakan media informasi yang sedang terjadi maupun yang sudah terjadi baik di indonesia atau di luar negeri, berita juga dapat disajikan melalui media cetak atau media online. Akibat banyaknya berita yang tersaji secara offline, maka dibutuhkan sebuah metode pencarian informasi yang efektif dan efisien untuk mencari berita yang diinginkan, dikarnakan saat ini banyak sekali berita offline yang kurang akurat dan hoaxs. Khususnaya di wilayah Indonesia yang banyak terjadi berita-berita menarik,namun banyak sekali berita penyimpangan. Adapun penelitian ini bermaksudkan untuk mengklasifikasikan sekumpulan berita-berita ofline yang terjadi di Indonesia dengan menggunakan metode Extended Boolean . Pengujian algoritma ini dilakukan dengan mengambil sampel dari media yang berbasis koran, majalah, tabloid, boklate dan bentuk lainnya. Pemilihan poin (treshold) yang tepat akan meningkatkan kualitas information retrieval pada sebuah data.
\end{abstract}

Kata kunci: Information retrieval, Boolean Information Retrieval (BIR), Berita offline.

\section{ABSTRACT}

News is a medium of information that is currently happening or what has happened both in Indonesia and abroad, news can also be presented through print or online media. Due to the large number of news presented offline, an effective and efficient information search method is needed to find the desired news, because currently there are so many inaccurate offline news and hoaxes. Especially in the territory of Indonesia where a lot of interesting news occurs, but a lot of irregularities. This study intends to classify a set of offline news occurring in Indonesia using the Extended Boolean method. This algorithm test is done by taking samples from media based on newspapers, magazines, tabloids, boklate and others. Selection of the correct points (threshold) will improve the quality of information retrieval in a data.

Keywords: Retrieval information, Boolean Information Retrieval (BIR), Offline news

\section{PENDAHULUAN}

Perkembangan globalisasi merupakan realita yang harus dihadapi oleh semua orang, dimana kita dituntut untuk bergerak cepat pada semua aktifitas. Begitu juga dengan sebuah kabar berita. Dengan adanya sebuah berita yang belum terkomputerisasi atau berbasis offline sehingga banyak berita tentang 
realita dunia yang banyak tidak diketahui oleh masyarakat sekitar, sehingga dengan adanya suatu berita offline yang terkomputerisasi yang akan memungkinkan dapat dengan mudah mengakses informasi dengan cepat. Kemajuan teknologi informasi yang begitu cepat pada jaman sekarang ini serta potensi pemanfaatannya yang sangat luas, sehingga telah membuka peluang untuk semua individu dapat mengakses, mengolah, dan memperoleh informasi dalam volume yang besar secara cepat. Sejatinya Informasi yang diinginkan dapat tersaji dalam beragam media. Masyarakat lebih sering mengakses informasi melalui handphone pintarnya karena alat tersebut merupakan alat paling mudah untuk dibawa kemanapun dan kapanpun masyarakat beraktivitas. Sementara pemerataan pembangunan penunjang saluran informasi masih diupayakan oleh pemerintah. Indonesia merupakan Negara kepulauan yang memiliki luas wilayah tidak kurang dari 1.916.906 $\mathrm{Km}^{2}$. ("Badan Pusat Statistik," 2021) yang terdiri dari pulau pulau dan tersebar di nusantara, pemerataan jaringan internet di Indonesia belum terdistribusi maksimal, Pemerintah masih berupaya keras untuk memperbaiki infrastruktur di berbagai daerah terutama daerah timur Indonesia.

Disisi lain masih banyak pemberitaan atau sajian informasi yang disuguhkan dalam bentuk cetak atau offline, beberapa media masa besar masih mengandalkan media cetaknya sebagai upaya penyampaian informasi pada khalayak banyak dengan kelas usia tertentu. Meski perkembangan transisi era digital akan menghilangkan sedikit demi sedikit berita yang disajikan offline. Namun dalam beberapa tahun kedepan berita offline diprediksi masih eksis baik di kota besar seperti Jakarta, Bandung, Surabaya atau daerah penyangga kota besar seperti Bekasi, Karawang dan kota lainnya karena pemerataan penggunaan media inforamsi berbasis internet belum merata ke semua daerah Indonesia.

Sehingga berita offline masih menjadi media efektip menyampaikan informasi kepada masyarakat Indonesia secara luas, meski kecepatannya kalah dengan media elektronik. Realitanya sebahagian berita offline masih juga banyak berita yang menyimpang dalam realita kehidupan atau hoaxs sehingga tidak sesuai dengan apa yang kita harapkan. Maka karena itu di butuhkan suatu system pemberian berita offline secara terklasifikasi yang diharapkan memberikan 
kemudahan untuk mendapatkan informasi yang tepat dan akurat ataupun apa yang kita butuhkan. Dari permasalahan tersebut, sehingga membutuhkan perancangan suatu sistem pengelompokan berita yang offline secara terklasifikasi sedangkan metode extended Boolean untuk membantu mempermudah proses pencarian informasi berita offline yang terklasifikasi di Indonesia.

\section{METODE PENELETIAN}

Penelitian ini diambil dengan melakukan survei dari paper yang tersedia dari hasil penelitian yang terbit di jurnal nasional atau pun internasional dan yang dipublikasikan dalam seminar nasional dengan tema pembahasan di bidang klasterisasi, klasifikasi dan peringkasan teks berbahasa Indonesia yang dapat mempermudah berita secara tepat. Paper yang didapatkan kemudian dilihat dan di tinjau dari metode-metode yang digunakan dalam proses penambangan data-data dalam analisa jurnal tersebut, baik sebelum dilakukan proses dan sesudah prosesnya dilakukan. Survei juga melihat banyaknya data-data yang di dapatkan dalam pengujian yang digunakan tingkat akurasi atau ketepatan dalam konten yang didapatkan. Dalam survei ini juga melihat secara umum metode penulisan paper yang dilakukan (Raharjo \& Winarko, 2014).

Berita merupakan media informasi yang sedang terjadi maupun yang sudah terjadi baik di Indonesia maupun di luar negeri, berita juga dapat disajikan media cetak atau media online. Sebagai metode pengumpulan data pada penelitian ini menggunakan observasi. Sebagaimana Sugiyono menerangkan Observasi sebagai suatu proses yang komplek, suatu proses yang tersusun dari berbagai proses biologis dan psikologis (Walim \& Suhardi, 2020), Adapun populasi data yang diambil adalah: media cetak seperti majalah, koran, tabloid, booklate dan bentuk media cetak lainnya.

Sebagai Obyek, penelitian ini mengambil populasi. Populasi yang dimaksud adalah suatu bidang generalisasi yang terdiri dari objek atau mata pelajaran yang memiliki kualitas dan karakteristik tertentu yang ditentukan untuk dipelajari dan kemudian ditarik kesimpulan yang akan diambil (Suhardi, Widyastuti, Bisri, \& Prabowo, 2019). Adapun populasi berita yang diambil hanya berita-berita yang ada di Indonesia. Mengenai format dan karakteristik data adalah terstruktur, di 


\section{P-ISSN $2580-7781$}

E-ISSN $2615-3238$

karenakan tujuan dari mensortir berita untuk lebih terklasifikasi mengenai berita di Indonesia. Di Indonesia masih banyak ditemukan berita-berita yang menyimpang dalam kontexs pencarian, sehingga berita tersebut tidak sesuai yang kita harapkan. Seperti contoh menggunakan kalimat yang tidak SPOK dan tidak menggunakan pola-pola dasar kalimat bahasa Indonesia dengan kerangka penelitian dapat dilihat pada gambar berikut:

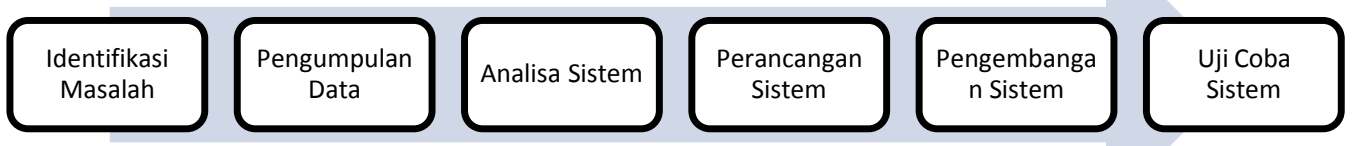

Gambar 1. Kerangka Kerja

1. Identifikasi Masalah

Dalam penelitian ini akan dibangun sebuah system klasifikasi berita dimana sistem tersebut dapat memfilter berita secara otomatis tidak diharapkan. Sehingga dari permasalahan ini dapat dibuatkan rumusan masalahnya mengenai berita yang terjadi di Indonesia yaitu : bagaimana mengklasifikasikan berita secara otomatis (Nurhadi, n.d.).

\section{Perancangan}

Perancangan sistem merupakan penggambaran, perencanaan dan pembuatan sketsa atau pengaturan dari beberapa elemen yang terpisah ke dalam satu kesatuan yang utuh dan berfungsi (Mulyani, 2017) Tahap perancangan sistem mempunyai dua maksud atau tujuan utama yaitu:

a. Untuk memenuhi kebutuhan pemakai sistem mencari suatu klasifikasi berita.

b. Untuk memberikan gambaran yang jelas dan rancang bangun yang lengkap kepada pemrograman komputer dan ahli-ahli teknik lainnya yang terlibat supaya proses pengklasifikasian dapat dilakukan dengan mudah (Muslihudin, 2016)

Untuk memahami tujuan ini, analisa sistem harus dapat mencapai sasaransasaran sebagai berikut:

a. Implementasi sistem harus berguna, mudah dipahami dan nantinya mudah 
digunakan.

b. Implementasi sistem harus dapat mendukung tujuan utama perusahaan sesuai dengan yang didefiniskan pada tahap perencanaan sistem yang dilanjutkan pada tahap analisa sistem.

\section{Sistem}

Sistem berasal dari bahasa Yunani yaitu "sistema" yang artinya kesatuan. Suatu sistem adalah jaringan kerja dari prosedur-prosedur yang saling berhubungan, berkumpul bersama-sama untuk melakukan kegiatan atau untuk mencapai suatu sasaran tertentu. Ada berbagai macam definisi mengenai sistem. Sistem pada dasarnya adalah sekelompok unsur yang erat hubungannya satu dengan yang lain, yang berfungsi bersama-sama untuk mencapai tujuan tertentu (Sutabri, 2016).

Sistem adalah jaringan kerja dari prosedur-prosedur yang saling berhubungan, berkumpul bersama-sama untuk melakukan kegiatan dalam rangka mencapai tujuan tertentu (Tabrani, Suhardi, \& Priyandaru, 2021). Sistem mempunyai beberapa komponen, diantaranya adalah :

a. Perangkat keras, meliputi CPU, disk, terminal, printer, dan tape.

b. Perangkat lunak meliputi sistem operasi, sistem database, program pengontrol komunikasi, dan program aplikasi.

c. Personil meliputi orang yang mengoperasikan sistem, menyediakan masukan, dan melakukan aktivitas manual yang mendukung sistem.

d. Data meliputi komponen yang harus tersimpan dalam sistem selama jangka waktu tertentu.

e. Prosedur meliputi instruksi dan kebijakan untuk mengoperasikan sistem. Jadi, sistem merupakan kumpulan dari bagian-bagian atau elemen-elemen yang saling berhubungan dan terpadu untuk mencapai suatu tujuan tertentu (Nopriandi, 2018).

\section{Pencarian}

Pencarian (searching) merupakan pekerjaan yang sering dilakukan dalam kehidupan sehari-hari. Dalam text editor, sering dilakukan pekerjaan untuk mencari kata, atau mencari "kata1" dan menggantikannya dengan "kata2", atau 


\section{P-ISSN $2580-7781$}

E-ISSN $2615-3238$

mencari kata tertentu dan menghitung frekuensi kemunculan kata tersebut dalam dokumen (Situmorang, 2017). Windows explorer dan internet explorer dalam sistem operasi Windows menggunakan prinsip pencarian dalam melakukan pekerjaan dimaksud. Dalam ilmu komputer, metode pencarian (searching) ada bermacam macam. Secara garis besar, metode pencarian data dapat dibagi menjadi 2 bagian, yaitu:

a. Metode pencarian data tanpa penempatan data, terdiri dari Metode pencarian Linier (Linear / Sequential Search), Metode pencarian Biner (Binary Search), Metode pencarian Interpolasi (Interpolation Search).

b. Metode pencarian data dengan penempatan data, terdiri dari metode pencarian langsung (Direct Search) dan metode pencarian relatif (Hash Search) (Syahputra, 2016).

Masing-masing metode memiliki kelebihan dan kekurangan. Metode pencarian yang memiliki efisiensi penggunaan tempat yang lebih baik adalah metode pencarian relatif (Hash Search).

5. Sistem Temu Kembali Informasi

Sistem information retrival adalah merupakan suatu system yang menemukan (retrieve) informasi atau berita yang dimaksud sehingga sesuai yang di harapkan dengan kebutuhan user dari kumpulan informasi-informasi berita secara otomatis. Prinsip kerja sistem information retrival jika ada sebuah kumpulan dokumen-dokumen dan seorang user yang memformulasikan sebuah pertanyaan atau permintaan (request atau query). Maka jawaban dari pertanyaan tersebut adalah sekumpulan dokumen-dokumen yang relevan atau yang akurat sehingga dapat membuang dokumen yang tidak relevan (Amin, 2013) 


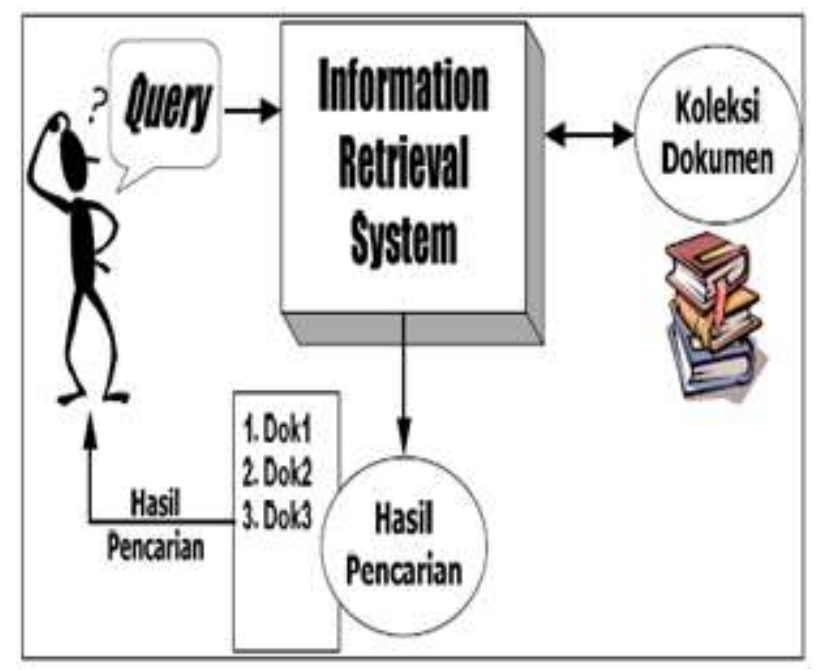

Gambar 2. Ilustrasi temu kembali

\section{Arsitektur Sistem Temu Kembali Informasi}

Proses Sistem information retrival adalah seperti pada Gambar 1 menggunakan arsitektur yang sederhana untuk bisa mencari suatu berita. Sebelum dilakukannya proses temu kembali diperlukan pendefinisian database. Selanjutnya dari proses awal sudah dilaksanakan kita tinggal mengikuti tahapan proses; Dokumen-dokumen yang akan digunakan tentang klasifikasi berita tersebut, Operasi yang akan digunakan dalam pencarian, dan model pengolahan teks (Sanjaya, 2017)

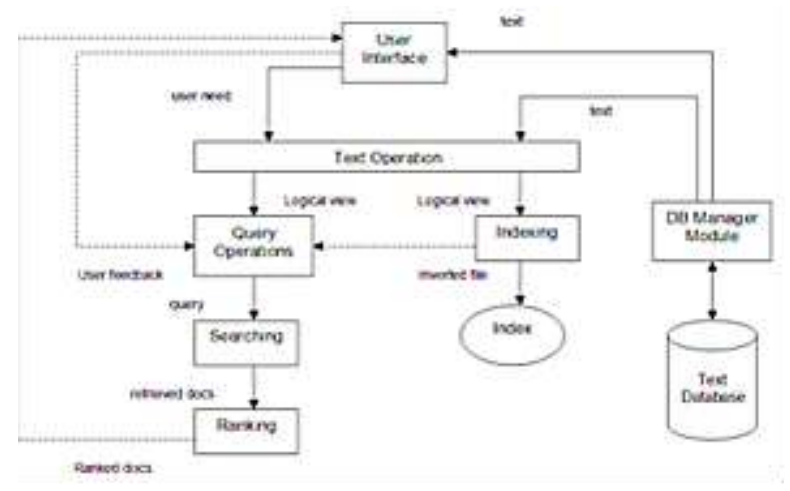

Gambar 3. The process of retrieving information

\section{Metode Extended Boolean}

Model Extended Boolean berdasarkan model P-norm merupakan pengembangan lebih lanjut dari model Boolean. Teknik ini memakai operator yang dikomputasi berdasarkan rumus Savoy (Kiswanto, 2013). Rumus masing- 


\section{P-ISSN $2580-7781$}

E-ISSN $2615-3238$

masing operator dapat dilihat pada tabel 1 ("Perancangan Information Retrieval System Dengan Metode Extended Boolean ," 2015). Metode Metode Extended Boolean memiliki rumusan secara matematis dan dapat diilustrsikan (Nanang, 2011). Perumusan ini dapat dilihat dalam tabel berikut:

Tabel 1. Metode Extended Boolean

\begin{tabular}{|l|l|}
\hline Query & Retrieval Status Value (RSV) \\
\hline $\mathrm{A}$ or $<\mathrm{p}>\mathrm{B}$ & $\mathrm{RSV}_{\mathrm{or}}=\sqrt[f]{\frac{W_{i s}^{p}+W_{i p}^{p}}{2}}$ \\
\hline $\mathrm{A}$ and $<\mathrm{p}>\mathrm{B}$ & $\mathrm{RSV}_{\mathrm{and}}=1-\sqrt[p]{\frac{\left(1-W_{i q}\right)^{p}+\left(1-W_{i b}\right)^{p}}{2}}$ \\
\hline Not A & $\mathrm{RSV}_{\mathrm{not}}=1-W_{i s}$ \\
\hline
\end{tabular}

\section{HASIL DAN PEMBAHASAN}

Dalam bagian ini akan dilakukan pembahasan mengenai survei atau rangkuman yang dilakukan dalam paper yang sudah ada untuk bisa mendapatkan hasil dari pengklasifikasian berita. Hasil penelusuran pustaka mendapatkan bahwa penelitian di bidang pemrosesan dokumen teks berbahasa Indonesia dimulai pada tahun 2000 (Raharjo \& Winarko, 2014). Walaupun penelitian ini tidak secara khusus melakukan klasifikasi berita di seluruh dunia dikarenakan hanya mengambil di wilayah Indonesia tapi begitu bermanfaat untuk para pencari berita yang khusus di Indonesia karena Indonesia banyak berita-berita yang menarik, klasterisasi atau peringkasan dokumen namun penelitian awal ini secara umum dapat disebutkan sebagai pengklasifikasian dokumen berita baik itu yang secara video atau secara teks dengan membuat indeks. Hasil survey menemukan bahwa terdapat berita-berita yang kurang baik atau tidak sesuai dengan yang kita harapkan, dalam tata cara pengklasifikasiannya aupun seperti permasalahan penulisan berita-berita yang dimaksud (Raharjo \& Winarko, 2014). Sebagai proses penyimpanan informasi secara terorganisir dapa dilihat pada gambar berikut: 


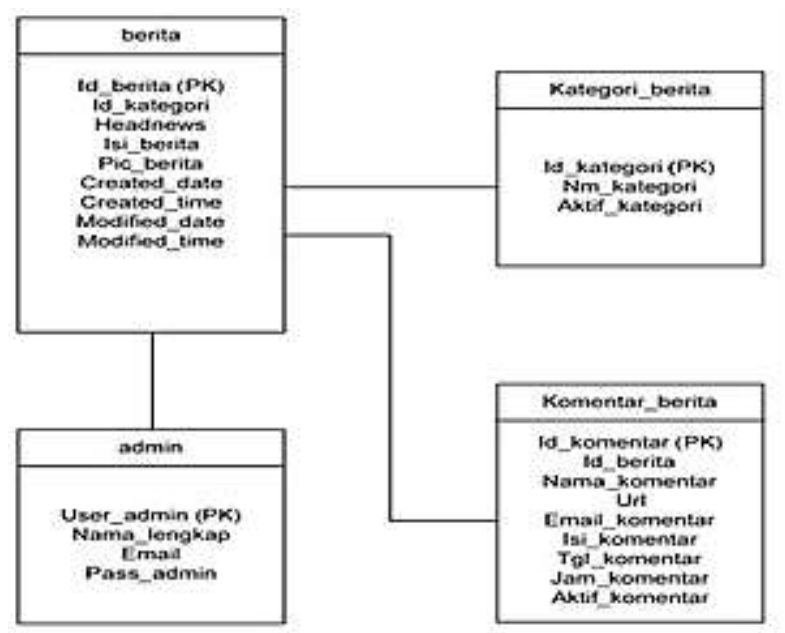

Gambar 4. Organisasi penyimpanan informasi

Untuk sintaks pencarian informasi dengan menggunakan serch seperti google tetapi harus menggunakan pola kalimat dasar bahasa Indonesia.
A) $\mathrm{S}-\mathrm{P}$
B) $\mathrm{S}-\mathrm{P}-\mathrm{O}$
C) S-P-PEL
D) S-P-O-PEL
E) S-P-O-PEL-K
F) S-P-K
G) S-P-O-K
H) S-P-PEL-K

Proses pencarian informasi terjadi interaksi antara pengguna dengan sistem (mesin), baik secara langsung maupun tidak langsung. Interaksi antara pengguna dengan sistem dalam proses pencarian informasi dapat dinyatakan sebagai berikut: 


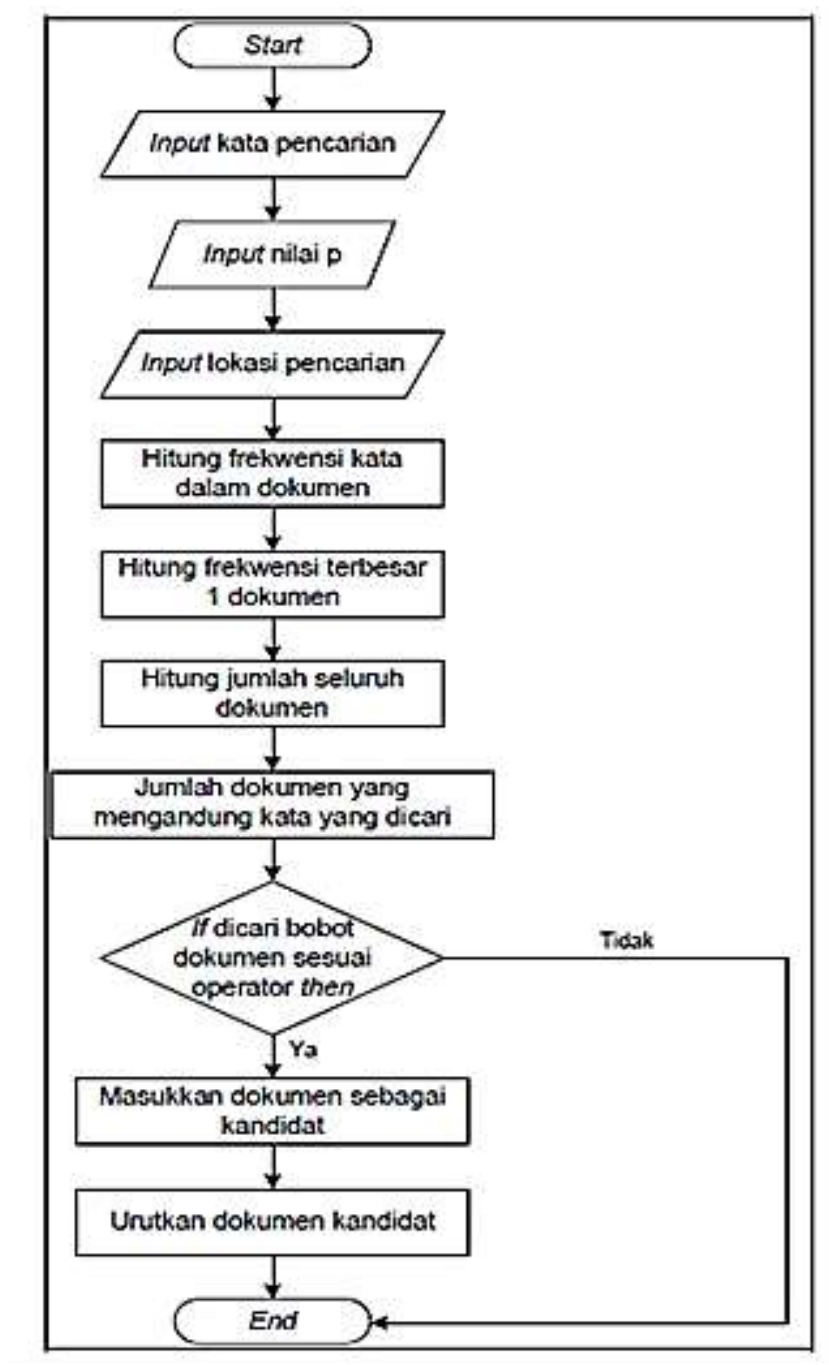

Gambar 5. Proses pencarian dokumen

Teks dalam dokumen yang didapatkan dari berbagai berita online kemudia akan dicari algoritmanya dengan melakukan langkah berikut:

1. Dokumen direprentasikan dalam ruang secara melihat kordinasi.

2. Kordinator $\mathrm{x}, \mathrm{y}$ dan $\mathrm{z}$ ditentukn dengan menggunakan kamus besar.

3. Tergantung dalam konjungction dan disjungction.

Sedangkan tahap untuk melakukan konjungction dapat dilakukan dengan cara sebagai berikut:
a. Menentukan vector jarak dari $(0,0)$.
b. Menentukan vector jarak dari $(1,0)$
c. Menggunakan konsep p-porm.
d. Perluasan karakteristik dari extend Boolean 


\section{P-ISSN 2580 - 7781}

E-ISSN $2615-3238$

e. Menghitung jarak.

Misalkan ada sebuah kumpulan dokumen dan seorang user yang memformulasikan sebuah pertanyaan (request atau query). Jawaban dari 11 pertanyaan tersebut adalah sekumpulan dokumen yang relevan dan membuang dokumen yang tidak relevan.

Secara matematis hal tersebut dapat dituliskan sebagai berikut:

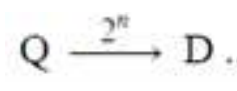

Gambar 6. Rumus Query

Dimana:

$\mathrm{Q}=$ pertanyaan (query)

$\mathrm{D}=$ dokumen

$\mathrm{n}=$ jumlah dokumen

$2 \mathrm{n}=$ jumlah kemungkinan himpunan bagian dari dokumen yang ditemukan

Sistem Temu Kembali pada dasarnya dibagi dalam dua komponen utama yaitu sistem pengindeksan (indexing) yang menghasilkan basis data sistem dan temu kembali yang merupakan gabungan dari user interface dan look-up-table. Pada bagian selanjutnya akan dijelaskan mengenai sistem pengindeksan dan teknik temu kembali informasi. Sistem Temu Kembali didesain untuk menemukan dokumen atau informasi yang diperlukan oleh masyarakat pengguna. Information retrieval system bertujuan untuk menghubungkan kebutuhan informasi pengguna dengan sumber informasi. Information retrieval system bertujuan untuk mempertemukan ide yang dikemukakan oleh user dalam dokumen dengan kebutuhan informasi pengguna yang dinyatakan dalam bentuk pertanyaan (query). Berkaitan dengan sumber informasi di satu sisi dan kebutuhan informasi pengguna di sisi yang lain, information retrieval system berperan untuk:

1. Menganalisa isi sumber informasi dan pertanyaan pengguna.

2. Mempertemukan pertanyaan pengguna dengan sumber informasi untuk mendapatkan dokumen yang relevan.

Adapun fungsi utama information retrieval system adalah sebagai berikut:

1. Mengidentifikasi sumber informasi yang relevan dengan minat masyarakat pengguna yang ditargetkan. 


\section{P-ISSN 2580 - 7781}

E-ISSN $2615-3238$

2. Menganalisa isi sumber informasi (dokumen).

3. Merepresentasikan isi sumber informasi dengan cara tertentu yang memungkinkan untuk dipertemukan dengan pertanyaan (query) pengguna.

4. Merepresentasikan pertanyaan (query) pengguna dengan cara tertentu yang memungkinkan untuk dipertemukan sumber informasi yang terdapat dalam basis data.

5. Mempertemukan pernyataan pencarian dengan data yang tersimpan dalam basis data.

6. Menemu-kembalikan informasi yang relevan.

7. Menyempurnakan unjuk kerja sistem berdasarkan umpan balik yang diberikan oleh pengguna.

Information retrieval system terdiri dari 5 (lima) subsistem, yaitu:

1. Subsistem dokumen

2. Subsistem pengindeksan

3. Subsistem kosa kata

4. Subsistem pencarian

5. Subsistem penyesuaian.

\section{KESIMPULAN}

1. Kehandalan Pencarian: tingkat akurasi pencarian berita dengan menggunakan Extended Boolean adalah masih belum terlalu akurat karena masih ada kekurangan dari metode Extended Boolean ini salah satunya tidak menggunakan CACHE.

2. Kelebihan dan Kekurangan metode Extended Boolean.

a. Model Boolean merupakan model sederhana yang menggunakan teori dasar himpunan sehingga mudah di implementasikan.

b. Metode Boolean dapat diperluas dengan menggunakan proximbiy operator dan wildcard operator .

c. Adanya pertimbangan biaya untuk mengubah software dan structure database, terutama pada system komersir.

d. Tidak bisa menggunakan parctial matching pada kupri.

e. Model Boolean tidak menggunakan peringkat dokumen yang terambil, 
dokumen yang terambil hanya dokumen yang benar-benar sesuai dengan pernyataan Boolean/Query yang diberikan sehingga document yang terambil bisa sangat banyak atau sedikit. Akibatnya ada kesulitan dalam mengambil keputusan.

f. Teori himpunan memang mudah namun tidak demikian dengan halnya pernyataan Boolean yang bisa komplexs, akibatnya pengguna harus memiliki pengetahuan banyak mengenai Query dengan Boolean agar pencarian menjadi efisien.

\section{SARAN}

1. Metode Boolean ini akan dikembangkan lagi sehingga dapat menyelesaikan particial matching pada query dengan tambahan cache sehingga dapat cepat dan mudah dalam pencarian.

2. Dokumen yang terambil bisa bukan hanya dokumen yang benar benar sesuai dengan Boolean.

\section{DAFTAR PUSTAKA}

Amin, F. (2013). Sistem Temu Kembali Informasi dengan Pemeringkatan Metode Vector Space Model. Dinamik, 18(2).

Badan Pusat Statistik. (2021). Retrieved from https://www.bps.go.id/

Kiswanto, M. A. (2013). APLIKASI INFORMATION RETRIEVAL PENCARIAN PUSTAKA DIGITAL BERDASARKAN TINGKAT KEMIRIPAN MENGGUNAKAN METODE EXTENDED BOOLEAN. UPN" Veteran" yogyakarta.

Mulyani, S. (2017). Metode Analisis dan perancangan sistem. Abdi Sistematika.

Muslihudin, M. (2016). Analisis Dan Perancangan Sistem Informasi Menggunakan Model Terstruktur Dan UML. Penerbit Andi.

Nanang, H. (2011). PANEGEMBANGAN SISTEM MANAJEMEN PERUNDANGUNDANGAN MENGGUNAKAN MODEL PENCARIAN EXTENDED BOOLEAN.

Nopriandi, H. (2018). Perancangan sistem informasi registrasi mahasiswa. Jurnal Teknologi Dan Open Source, 1(1), 73-79.

Nurhadi, A. (n.d.). Klasifikasi Konten Berita Digital Bahasa Indonesia Menggunakan Support Vector Machines (SVM) Berbasis Particle Swarm Optimization (PSO). Retrieved from https://ejournal.bsi.ac.id/ejurnal/ index.php/Bianglala/article/view/541/433 
Raharjo, S., \& Winarko, E. (2014). Klasterisasi, klasifikasi dan peringkasan teks berbahasa indonesia. Prosiding KOMMIT.

Sanjaya, F. (2017). Pemanfaatan Sistem Temu Kembali Informasi dalam Pencarian Dokumen Menggunakan Metode Vector Space Model. JINTECH, 5(02), 147-153.

Situmorang, H. (2017). ANALISA ALGORITMA PADA METODA PENCARIAN LINIER, BINER DAN INTERPOLASI. Jurnal Mahajana Informasi, 2(2), 31-41.

Suhardi, S., Widyastuti, T., Bisri, B., \& Prabowo, W. (2019). FORECASTING ANALYSIS OF NEW STUDENTS ACCEPTANCE USING TIME SERIES FORECASTING METHOD. Jurnal Akrab Juara, 4(5), 10-23.

Sutabri, T. (2016). Sistem informasi manajemen.

Syahputra, G. (2016). Implementasi Teknik Binary Search Pada Kamus Indonesia-Batak Toba. Journal Of Informatic Pelita Nusantara, 1(1).

Tabrani, M., Suhardi, S., \& Priyandaru, H. (2021). SISTEM INFORMASI MANAJEMEN BERBASIS WEBSITE PADA UNL STUDIO DENGAN MENGGUNAKAN FRAMEWORK CODEIGNITER. JURNAL ILMIAH M-PROGRESS, 11(1).

Walim, W., \& Suhardi, S. (2020). RANCANG BANGUN SISTEM INFORMASI E-COMMERCE DALAM PENJUALAN HARDWARE KOMPUTER BERBASIS WEBSITE. CERMIN: Jurnal Penelitian, 4(2), 317-338. 